\title{
Molecular characterization of central cytoplasmic loop in Aspergillus nidulans AstA transporter
}

\author{
Sebastian Piłsyk ${ }^{1 凶}$, Marzena Sieńko1, Jerzy Brzywczy¹, Maciej P. Golan², \\ Urszula Perlińska-Lenart ${ }^{1}$ and Joanna S. Kruszewska ${ }^{1}$ \\ IInstitute of Biochemistry and Biophysics, Polish Academy of Sciences, Warsaw, Poland; ${ }^{2}$ Opta - Tech Co. Ltd., Warsaw, Poland
}

\begin{abstract}
AstA (alternative sulfate transporter) belongs to a large, but poorly characterized, Dal5 family of allantoate permeases of the Major Facilitator Superfamily. The ast $A$ gene has been cloned from an IAM 2006 Japanese strain of Aspergillus nidulans by complementation of a sulfate permease-deficient mutant. In this study we show that conserved lysine residues in Central Cytoplasmic Loop (CCL) of the AstA protein may participate in anion selectivity, and control kinetic properties of the AstA transporter. A three-dimensional model containing four clustered lysine residues was created, showing a novel substrate-interacting structure in Major Facilitator Superfamily transporters. The assimilation constant $\left(K_{\tau}\right)$ of wild type AstA protein is $85 \mu \mathrm{M}$, while $V_{\max } / \mathrm{mg}$ of DW of AstA is twice that of the main sulfate transporter SB per $\mathrm{mg}$ of dry weight (DW) of mycelium (1.53 vs. $0.85 \mathrm{nmol} / \mathrm{min}$, respectively). Amino acid substitutions in CCL did not abolish sulfate uptake, but affected its kinetic parameters. Mutants affected in the lysine residues forming the postulated sulfate-interacting pocket in AstA were able to grow and uptake sulfate, indicating that CCL is not crucial for sulfate transportation. However, these mutants exhibited altered values of $K_{\tau}$ and $V_{\text {max }}$, suggesting that $\mathrm{CCL}$ is involved in control of the transporter activity.
\end{abstract}

Key words: Aspergillus nidulans, sulfate permease, alternative sulfate transporter, AstA, intracellular loop, mutagenesis

Received: 28 May, 2018; revised: 03 July, 2018; accepted:

20 September, 2018; available on-line: 14 November, 2018

¿e-mail: Seba@ibb.waw.pl

Abbreviations: CCL, central cytoplasmic loop; MFS, major facilitator superfamily; SMR, sulfur metabolite repression; TM, transmembrane; $K_{\tau}$, assimilation constant; $P C R$, polymerase chain reaction; OE-PCR, overlap extension polymerase chain reaction

\section{INTRODUCTION}

Sulfate is taken up and utilized for the synthesis of organic sulfur compounds by bacteria, fungi and plants. In eukaryotes, sulfate uptake is carried out by sulfate permeases from the SulP family (Kertesz 2001; Loughlin et al., 2002; Piłsyk \& Paszewski 2009; Alper \& Sharma 2013). These proteins are assigned to the TC 2.A.53 class, according to the Transporter Classification (TC) system. In Aspergillus nidulans the main sulfate permease is encoded by the $s B$ gene, however, an alternative sulfate transporter (AstA) is also functional in some $A$. nidulans strains. The ast $A$ gene has been cloned earlier from a genomic library of the Japanese IAM 2006 strain, as a suppressor complementing sulfate permease-deficiency of the $s B$ mutant (Piłsyk et al., 2007). The ast $A$ gene is regulated at the transcriptional level by sulfur metabolite repression (SMR), being derepressed under sulfur limitation conditions. In the reference $A$. nidulans strains of Glasgow origin ast $A$ is non-functional, thus, $\mathrm{SB}$ is the only sulfate permease in these strains. Recently, it was shown that AstA transports also sulfite and choline sulfate (Holt et al., 2017). Orthologues of ast $A$ occur frequently in evolutionarily distant fungi belonging to the Dikarya phylum with often common feature of plant or animal pathogenicity. An ast $A$ orthologue identified from pathogenic Fusarium sambucinum fungus was found to be derepressed during potato tuber infection, where the AstA protein may efficiently take up sulfate (Piłsyk et al., 2015).

The $A$. nidulans AstA protein $\left(\mathrm{GenBank}^{\circledR}\right.$ accession number ABA28286) is a member of the poorly characterized Dal5 allantoate permease family belonging to the Major Facilitator Superfamily (MFS, TC 2.A.1). The MFS transporters are localized in the cell membrane or in organellar membranes facilitating the transport of various substrates (ions, sugars, drugs, neurotransmitters, amino acids, or peptides). Contrary to ATP-dependent SulP family of sulfate permeases (Tweedie \& Segel, 1970, Woodin \& Wang, 1989), three different mechanisms of transport via MFS transporters are distinguished: uniporters transporting one type of substrate and energized by its gradient, symporters translocating simultaneously two or more substrates and drawing energy from the electrochemical gradient of one of them, and antiporters transporting two or more substrates in opposite directions (Law et al., 2008; Iancu et al., 2013; Ethayathulla et al., 2014; Patron et al., 2014). The AstA transporter can uptake sulfate in proton symport-driven energy (Holt et al., 2017). Until now, only one report presented experimental evidence for ATP-independence of MFS - the gene encoding Hxt13p hexose transporter was cloned while screening the yeast genomic library for resistance to antifungal drug miltefosine (Biswas et al., 2013). The authors have shown that Hxt13p acts as an ATP-independent efflux pump for miltefosine. On the other hand, it was shown that GLUT1 glucose transporter in human erythrocytes binds ATP, which triggers significant conformational changes in GLUT1 that lead to its inactivation (Blodgett et al., 2007). In this case ATP serves as low molecular weight effector rather than energy source.

Crystal structures of bacterial MFS transporters (FucP, LacY, GlpT, EmrD) have revealed the presence of 12 transmembrane (TM) alpha helices. These helices are clustered in the $\mathrm{N}$ - and C-terminal domains, each comprising six helices (Fig. 1) (Abramson et al., 2003; Lemieux et al., 2004; Yin et al., 2006; Dang et al., 2010). A similar structure of 12 TM helices has also been identified in another MFS phosphate transporter, the PiPT 


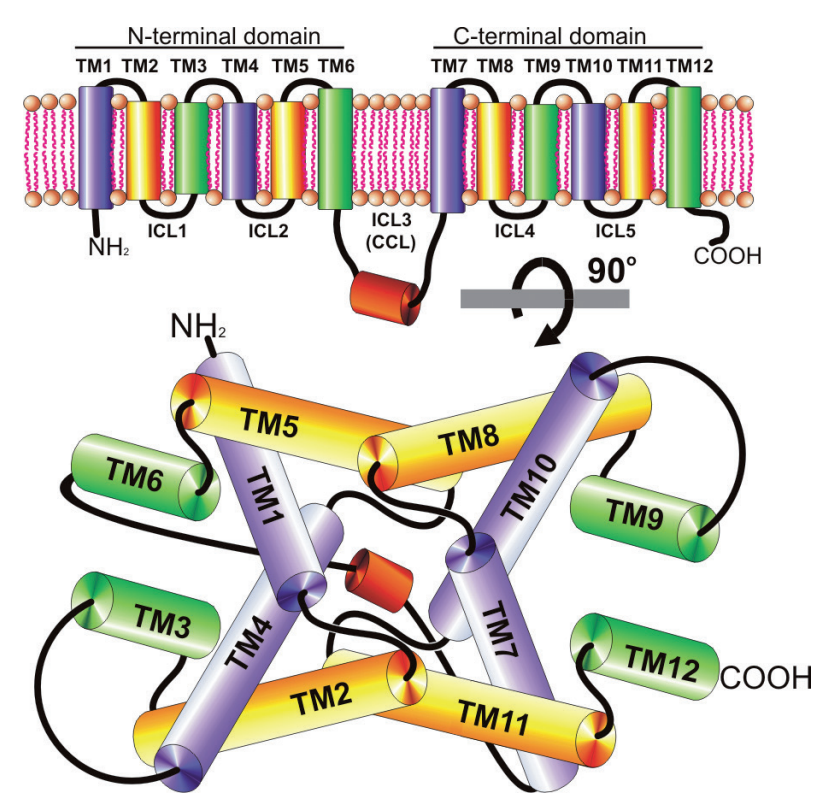

Figure 1. The predicted transmembrane topology of MFS transporters (upper) and their general 3D model (lower), based on known crystal structures (PDB IDs: 307Q, 2V8N, 1PW4, 2GFP, 4J05).

protein of the Piriformospora indica fungus (Pedersen et al., 2013). The substrate-binding residues are found in various TM helices: TM5 in the Candida albicans Mdr1p protein (Pasrija et al., 2007), TM7 in human GLUT-1 (Kasahara et al., 2009), TM1, TM5 and TM7 in E. coli GlpT and FucP (Lemieux et al., 2004; Dang et al., 2010), and TM5, TM 7, TM10 and TM11 in E. coli XylE (Sun et al., 2012). Between the N- and C-terminal domains of all MFS proteins, a third domain is present, called the Central Cytoplasmic Loop (CCL).

Substrate uptake mechanism of MFS transporters involves a rocker-switch type of movement, followed by transient formation and breakage of a salt bridge between positively and negatively charged amino acids located opposite in the apical surface of the TM helices (Law et al., 2008). Thus, CCL transiently forms a latch- like structure in the outward-facing open conformation, while in the inward-facing open conformation, it unfolds into a partially disordered chain and swings away from the substrate translocation pathway (Wisedchaisri et al., 2014). Additionally, CCL acts as a constraint for movement of the $\mathrm{N}$ - and C-terminal domains and permits a relatively large interdomain movement, which has implications for the substrate translocation mechanism (Law et al., 2008). It has also been shown that CCL is critical for efficient substrate transport by the C. albicans Mdr1 multidrug transporter (Mandal et al., 2012) and likely participates in formation of a substrate translocation pore.

In this study, we demonstrate that CCL of the $A$. nidulans AstA protein controls sulfate transport. The role of four conserved lysine residues in the A. nidulans AstA protein was analyzed using site directed mutagenesis. Interestingly, four single amino acid substitutions $\left(\mathrm{K}_{260} \mathrm{~A}\right.$, $\mathrm{K}_{263} \mathrm{~A}, \mathrm{~K}_{263} \mathrm{~L}$ and $\mathrm{K}_{264} \mathrm{~L}$ ), introduced in the substrate-interacting region of AstA, led to more selective uptake of sulfate compared to selenate.

\section{MATERIALS AND METHODS}

Strains and media. The Aspergillus nidulans strains from our collection, carrying standard markers (Clutterbuck 1994; Martinelli 1994), together with the Escherichia coli strain used in this study, are listed in Table 1. The M111 strain, derived from Glasgow wild-type, bearing the $s B 43$ mutation complemented with the $s B$ gene and carrying a non-functional ast $A$ gene, was used as the A. nidulans reference strain.

Growth conditions. The following media (solid and liquid) were used: complete medium (CM) (Cove, 1966) for protoplasts or DNA isolation, minimal medium (MM) or minimal sulfur free medium (MM-S) (Lukaszkiewicz \& Paszewski, 1976), the latter supplemented either with sulfate $(1 \mathrm{mM}$, inorganic sulfur) or L-methionine $(0.1 \mathrm{mM}$, organic sulfur). The minimal media were also supplemented according to the auxotrophic requirements of the cultured strain. Liquid cultures were grown at $37^{\circ} \mathrm{C}$ for 16 hours in a rotary shaker $(200 \mathrm{rpm})$. The culture doubling times were calculated using the Doubling Time Computing web page (Roth 2006). Escherichia coli was grown in the standard LB medium supplemented with antibiotics as described before (Sambrook et al., 1989).

Table 1. Growth rates of AstA transformants on solid and liquid MM-S media supplemented with $1 \mathrm{mM}$ sulfate, transportation constant and maximum velocity of sulfate transport to mycelia expressing SB or AstA variants. The results are average values from at least three biological replicates.

\begin{tabular}{llllll}
\hline Transformant & $\begin{array}{l}\text { Growth on solid } \\
\text { medium } \\
{[\mathrm{mm} / \mathrm{h}]}\end{array}$ & $\begin{array}{l}\text { Doubling time in liquid } \\
\text { medium } \\
{[\mathrm{h}]}\end{array}$ & $\begin{array}{l}\text { Sulfate uptake } \\
{[\mathrm{nmol} / \mathrm{min} / \mathrm{mg} \mathrm{DW}] \text { av. }}\end{array}$ & $K_{\mathrm{T}}[\mu \mathrm{mol}]$ & $V_{\max }[\mathrm{nmol} / \mathrm{min} / \mathrm{mg} \mathrm{DW}]$ \\
\hline TRSBWT & 0.23 & 6.70 & 1.50 & 108 & 0.85 \\
\hline TRAstAWT & 0.21 & 5.44 & 0.74 & 85 & 1.53 \\
\hline TRAstAK $_{260} \mathrm{~A}$ & 0.25 & 5.16 & 1.02 & 25 & 1.15 \\
\hline TRAstAK $_{260} \mathrm{~L}$ & 0.21 & 3.81 & 1.12 & 36 & 1.47 \\
\hline TRAstAK $_{262} \mathrm{~A}$ & 0.23 & 5.53 & 0.79 & 77 & 1.37 \\
\hline TRAstAK $_{262} \mathrm{~L}$ & 0.19 & 7.98 & 0.62 & 72 & 0.65 \\
\hline TRAstAK $_{263} \mathrm{~A}$ & 0.23 & 4.15 & 0.82 & 79 & 0.95 \\
\hline TRAstAK $_{263} \mathrm{~L}$ & 0.21 & 5.01 & 1.27 & 50 & 1.79 \\
\hline TRAstAK $_{264} \mathrm{~A}$ & 0.19 & 5.68 & 1.22 & 37 & 3.05 \\
\hline TRAstAK $_{264} \mathrm{~L}$ & 0.21 & 3.46 & 1.33 & 137 & 1.36 \\
\hline TRAstAK $_{260-264} \mathrm{~A}$ & 0.18 & 2.86 & 0.89 & 37 \\
\hline
\end{tabular}


Nucleic acids manipulations, plasmid construction and mutagenesis. The plasmids used in this study are listed in Table 1. Plasmids were propagated and isolated according to the standard procedures (Sambrook et al., 1989). A. nidulans DNA was isolated using a salting out method. The frozen mycelia were disrupted by grinding in liquid nitrogen, followed by immediate suspension in warm STEN buffer $(1 \%$ SDS, $100 \mathrm{mM}$ Tris pH 7.5, $50 \mathrm{mM}$ EDTA pH 8, 100 $\mathrm{mM} \mathrm{NaCl}$ ) (Sambrook et al., 1989). Polymerase chain reactions (PCR) were performed in a Techne Thermocycler. DNA was sequenced, and primers were synthesized by the DNA Sequencing and Oligonucleotide Synthesis Laboratory, Institute of Biochemistry and Biophysics, PAS. The sequences of the primers used are provided in supplementary Table $\mathrm{S} 1$. The kPMS11-52 plasmid carrying the wild-type ast $A$ gene (Piłsyk et al., 2007) was modified by an insertion of the Neurospora crassa pyr-4 selection cassette into the PvuII restriction site yielding the kPMS11-524 plasmid. The latter could be selected by uridine prototrophy and was used for construction of a series of plasmids bearing the mutated ast $A$ alleles. Selected lysine residues were changed to alanine or leucine using Overlap Extension PCR (OE-PCR) with Pfu polymerase (Thermo Scientific). Obtained PCR products were cleaved with the SnaBI and MunI restriction enzymes (Thermo Scientific) and ligated into the kPMS11-524 vector digested with the SnaBI and MunI restriction enzymes to replace the wild type ast $A$. These mutations were verified by DNA sequencing and introduced into the $A$. nidulans sulfate permease-deficient M111 strain bearing the sB43 mutation (Table 1 ).

A $3.3 \mathrm{~kb}$ PstI fragment of the non-functional $\Psi$ ast $A$ gene was excised from the kPB6-7 plasmid (Piłsyk et al., 2007) and inserted into kPG23B yielding

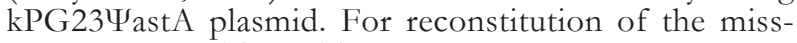
ing functional TM11-TM12 domains in $\Psi$ AstA, a 3.2 kb SpeI fragment from kPMS11-524 plasmid (last 586 nucleotides of ast A 3' ORF encoding TM11-TM12 together with $N$. crassa pyr-4 selection cassette) was ligated between SpeI restriction sites of kPB6-7 plasmid, yielding kPB611-12.

The Green Fluorescent Protein-labeled ast $A$ allele was constructed with OE-PCR of PCR-generated GFP with PCR-generated ast $A$ wild type allele using overlapping primers. The hybrid product was initially cloned into pGEM ${ }^{\circledR}$-T Easy vector (Promega), then excised with MunI-Van91I, and inserted into MunI-Van91I sites of kPMS11-524, yielding the kPMS11-5243 plasmid. Similarly, the same MunI-Van91I fragment was introduced into a series of kPMS11-524 derivatives bearing the mutated ast $A$ alleles.

Transformation of $\boldsymbol{A}$. nidulans strains. The mycelia for transformation were collected by filtration, washed with $0.6 \mathrm{M} \mathrm{KCl}$ and suspended in $0.6 \mathrm{M}$ $\mathrm{KCl}$ buffered with $10 \mathrm{mM}$ potassium phosphate $\mathrm{pH} 6.5$ and containing the following lytic enzymes: $15-20 \mathrm{mg} / \mathrm{ml}$ of Glucanex ${ }^{\circledR}$ (Novozymes), $2 \mathrm{mg} / \mathrm{ml}$ of Driselase ${ }^{\circledR}$ (Sigma-Aldrich) and $1 \mathrm{mg} / \mathrm{ml}$ of snail acetone powder (Sigma-Aldrich). The protoplasts were prepared and transformed using the PEG method (Kuwano et al., 2008). To increase transformation efficiency, $5 \mu \mathrm{g}$ of the HELp helper plasmid (Gems \& Clutterbuck, 1993) was added. Transformants were selected for uracil prototrophy on MM-S medium supplemented with $2 \mathrm{mM}$ sulfate and $1.2 \mathrm{M}$ sorbitol.

Sulfate uptake assay. The sulfate uptake analysis was performed as described previously (Piłsyk et al.,
2015) using $0.1 \mathrm{mM}$ methionine - supplemented MM-S for mycelia growing under derepressing conditions. Ten $\mathrm{ml}$ aliquots were taken after 2, 3, 5, 10, 15 and $20 \mathrm{~min}$ of incubation, and the sulfate transport rates (nmol/ mg dry weight) were calculated based on at least three measurements taken at different times.

For the estimation of the assimilation constant $\left(K_{\tau}\right)$, a cold sulfate was added to the final concentrations of $0.166,0.2,0.25,0.33,0.5$ and $1 \mathrm{mM}$, and incubations were carried out for $1 \mathrm{~h}$. Mycelia were treated as above and the initial rate of transport $(\mathrm{nmol} / \mathrm{min} / \mathrm{mg}$ dry weight) was calculated for each concentration of the sulfate, based on at least four measurements. These data were rendered as Hanes-Woolf plots, and linear regression was used for calculation of $V_{\max }$ from the slope, and $K_{\tau}$ from the ordinate axis intercept.

Confocal microscopy. The mycelia for microscopic observations were grown in liquid MM-S medium supplemented with $0.1 \mathrm{mM}$ methionine (derepressing conditions) for $18 \mathrm{~h}$ at $37^{\circ} \mathrm{C}$ in a rotary shaker $(200$ $\mathrm{rpm})$. The mycelia were harvested by filtration, suspended in fresh MM-S medium supplemented with 1 $\mathrm{mM}$ sulfate and kept at $37^{\circ} \mathrm{C}$ in a rotary shaker $(200$ $\mathrm{rpm})$. The mycelial samples were collected at time of the medium shift ( $\mathrm{t} 0$ ) and $5 \mathrm{~h}$ after the shift, and examined under a Nikon Eclipse TE2000-E inverted microscope (Nikon, Tokyo, Japan).

Membrane protein isolation. For protein isolation, the mycelia were grown as above (Confocal microscopy), and the samples were harvested just before and $5 \mathrm{~h}$ after a shift to repressing conditions. Next, the collected samples were ground in TM isolation buffer (30 mM Tris-HCl pH 7.4, 50 mM EDTA pH 8, $1 \%$ sorbitol, $0.05 \%$ Tween-20, $200 \mathrm{mM} \mathrm{NaCl}, 20$ $\mathrm{mM}$ dithiothreitol, $1 \mathrm{mM}$ PMSF, protease inhibitors Complete ${ }^{\mathrm{TM}}$-Roche), and the homogenate was centrifuged at $4000 \times g$ for $10 \mathrm{~min}$. The supernatants were centrifuged for $1 \mathrm{~h}$ at $50000 \times \mathrm{g}$ and the pelleted membrane fractions were used for Western dot-blots.

Immunodetection of AstA-GFP protein. Membrane proteins suspended in TM isolation buffer were subjected to the Immobilon $\mathrm{P}$ membrane (Milipore), and AstA-GFP protein was detected with rabbit anti- $\alpha$ GFP polyclonal antibodies (Life Technologies). Polyclonal rabbit antibodies raised against entire yeast Pma1p protein were used as an internal reference standard. Anti-rabbit IgG secondary antibodies conjugated to alkaline phosphatase (Sigma-Aldrich) were then applied as secondary antibodies. After washing, dots were visualized using BCIP/NBT (Promega).

Protein quantification. Protein concentration was estimated according to Lowry and others (Lowry et al., 1951).

Bioinformatics. Multiple alignments of protein sequences were generated using the MUSCLE software (URL: http://www.drive5.com/muscle/) (Edgar, 2004). Homology searches of the GenBank database (release 95.0) were carried out using the BLAST program (Altschul \& Lipman, 1990). Transmembrane topology was predicted basing on four independent algorithms: the PredictProtein server ver. 10.20.04 (https://www.predictprotein.org/) (Rost et al., 2004), TMpred (https://embnet.vital-it.ch/software/TMPRED_form.html) (Hofmann \& Stoffel 1993), PSIPRED (http://bioinf.cs.ucl.ac.uk/ psipred/) (Buchan et al., 2013) and SMART (http:// smart.embl-heidelberg.de/) (Letunic \& Bork 2017). Modeling of 3D structure and ligand binding were performed with the I-TASSER metaserver (Zhang, 2008; Roy et al., 


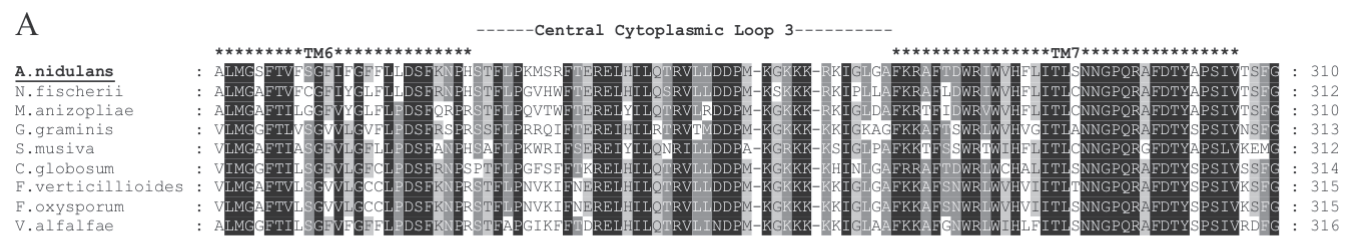

B

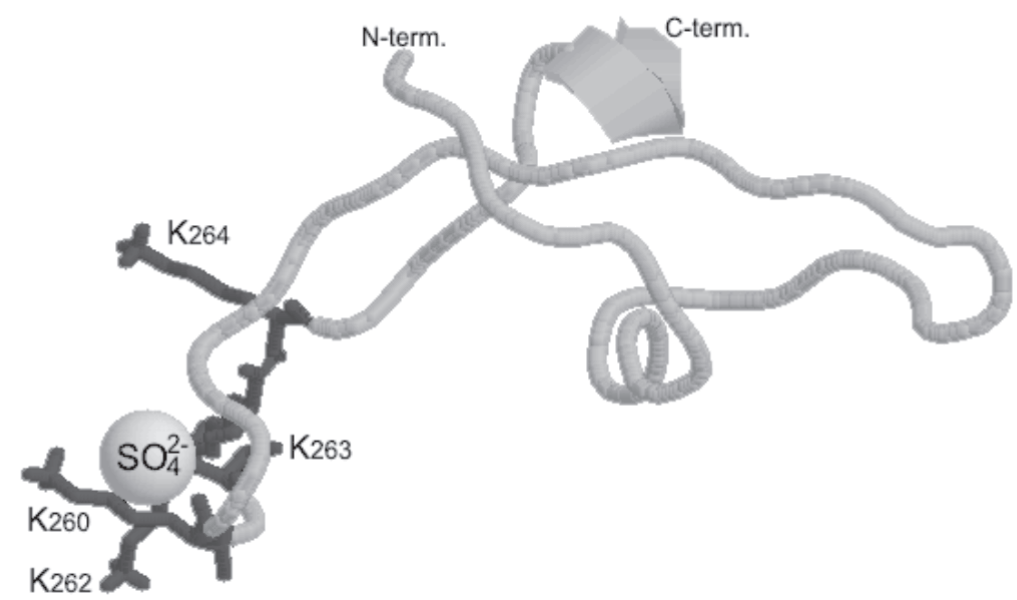

Figure 2. (A) Alignment of the Aspergillus nidulans AstA sequence with its orthologues from the Pezizomycotina subphylum. Conserved residues are dark-shaded. The Central Cytoplasmic Loop is located between transmembrane helices TM6 and TM7, which are marked with asterisks above the alignment. The highly conserved motif comprising four lysine residues is boxed. Access numbers of sequences are indicated in parentheses: Aspergillus nidulans (ABA28286), Neosartorya fischerii (NFIA_049850), Metarhizium anisopliae (MAA_07643), Gaeumannomyces graminis (GGTG_08696), Septoria musiva (SEPMUDRAFT_60592), Chaetomium globosum (CHGG_02116), Fusarium verticillioides (FVEG 12081), F. oxysporum (FOYG_01075) and Verticillium alfalfae (VDBG_07944).

(B) Structure of the Central Cytoplasmic Loop predicted by I-TASSER. Putative substrate-binding pocket comprises four lysine residues, which are marked in dark-grey and signed.

2010; Roy et al., 2012). The image of CCL was created with RasMol (Sayle \& Milner-White, 1995).

\section{RESULTS}

\section{Verification of astA allele functionality}

Our previous studies showed that $\mathrm{sB}$ mutants in A. nidulans could be complemented by the astA gene only when it was derived from the Japanese IAM2006 strain. Numerous attempts to complement the auxotrophic phenotype of $\mathrm{sB}$ mutants by a copy of astA derived from a reference wild-type strain of Glasgow origin, have failed (Piłsyk et al., 2007). Northern blot analysis of the ast $A$ expression in the reference strain showed no detectable signal. Moreover, comparison of the nucleotide sequences of astA ORFs in the Japanese and Glasgow strains suggested numerous mutations and deletions in the latter (Piłsyk et al., 2007), including lack of $187 \mathrm{bp}$ sequence putatively encoding TM11 and TM12 (Suppl. Fig. S1 at www.actabp.pl). These mutations might abolish the function of the putative AstA protein in the reference strain. Hence, we concluded that this allele exists as a pseudogene ( $\Psi$ astA). However, RNA-seq results allowed for a distinction of transcriptional unit in AspGD, and transcriptomic data indicate that the astA locus (AN10387) in the reference strain is transcribed (Cerqueira et al., 2014; Sieńko et al., 2014).

To verify functionality of the $\Psi$ astA gene, we generated two constructs bearing selectable N. crassa pyr4 cassette and the $\Psi$ astA gene or $\Psi$ astA fused with functional sequence coding for TM11-TM12 from the Japanese astA allele. However, transformation of sB mutant with these constructs did not restore sulfate prototrophy (see: Suppl. Fig. S1 at www.actabp.pl). Thus, the lack of TM11 and TM12 helices was not the only reason for abolishing function of the astA gene in strains of Glasgow origin, but the other mutations of the astA ORF present in theses strains were sufficient to abolish protein activity. Hence, in further studies a copy of the astA gene derived from the Japanese IAM2006 strain was used as a reference.

In silico analysis of the Central Cytoplasmic Loop. A predicted topology of the $A$. nidulans AstA transporter revealed twelve transmembrane domains and a centrally located CCL (Fig. 1), the latter domain containing four lysine residues clustered into a tight bundle located in the middle of CCL $-\mathrm{K}_{260}, \mathrm{~K}_{262}, \mathrm{~K}_{263}$ and $\mathrm{K}_{264}$. These four lysine residues, together with the fifth basic amino acid (arginine or lysine), are conserved in AstA orthologs from various fungal pathogens (Fig. 2A). We previously suggested that the positively charged CCL of AstA could be responsible for interaction with a negatively charged sulfate anion during translocation (Piłsyk et al., 2007). The Ast $\mathrm{A}$ region from $\mathrm{D}_{225}$ through $\mathrm{A}_{275}$ was modeled using the I-TASSER meta-server (Zhang, 2008; Roy et al., 2010; 2012) (Fig. 2B). Five similar models of the AstA CCL bound with sulfate were obtained, and the highest-scoring one (Fig. 2B) was used in further studies. This model exhibits a small ligand-binding region comprising amino acids 260 through 264 and resembling the calcium-binding pocket of human frequenin (PDB ID: 1G8I, Bourne et al., 2001). The predicted sulfate- 


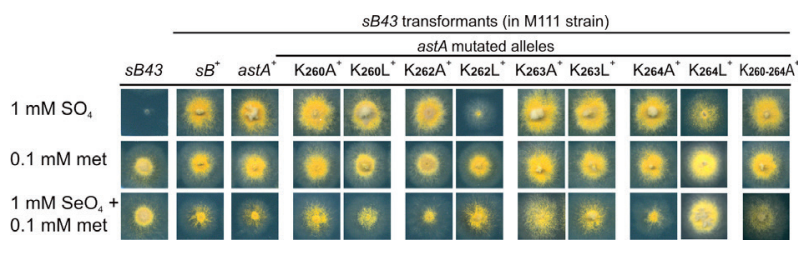

Figure 3. The growth of $A$. nidulans sB43 mutant transformed with various astA alleles.

Solid minimal sulfur-free medium (MM-S) was supplemented with $1 \mathrm{mM}$ sulfate, $0.25 \mathrm{mM}$ methionine or $0.25 \mathrm{mM}$ methionine with $1 \mathrm{mM}$ selenate. The sulfate permease-deficient recipient strain $(s B 43)$ and transformants with the wild type $s B$ or ast $A$ gene are included for comparison.

interacting pocket contains the four conserved lysine residues $\left(\mathrm{K}_{260}, \mathrm{~K}_{262}, \mathrm{~K}_{263}\right.$ and $\mathrm{K}_{264}$, see Fig. $\left.2 \mathrm{~B}\right)$, therefore, it seems likely that these lysine residues directly interact with the sulfate.

Central Cytoplasmic Loop mutants can grow. To check whether the lysine residues forming the predicted sulfate-interacting pocket $\left(\mathrm{K}_{260}, \mathrm{~K}_{262}, \mathrm{~K}_{263}\right.$ and $\left.\mathrm{K}_{264}\right)$ take part in sulfate transport, they were replaced individually with alanine or leucine, and additionally, a quadruple mutant with all four lysine residues changed to alanine was constructed. Small alanine residues are preferentially chosen as a substitution in site-directed mutagenesis, however, substitutions of lysine with leucine are also tested because of comparable size of these amino acids. Altogether, nine mutated ast $A$ alleles were generated using site-directed mutagenesis (Table 1). The functionality of the mutated ast $A$ alleles was tested by transformation of the $A$. nidulans M111 recipient strain, which bears non-functional ast $A$ gene and the sB43 mutation, and is hence unable to grow on sulfate as the sole sulfur source (Arst 1968; Piłsyk et al., 2007).

The obtained transformants were named by combining the TR letters denoting a transformant with the name of the modified protein and the amino acid substitution. Wild type alleles of ast $A$ and $s B$ were also introduced into the M111 recipient strain, yielding the TRAstAWT and TRSBWT transformants, respectively (Table 1).

Almost all the tested ast $A$ alleles complemented the $s B 43$ mutation, rendering the transformants able to grow on sulfate, both on solid and in liquid minimal media (Fig. 3, Table 1). The TRAst $\mathrm{AK}_{262} \mathrm{~L}$ mutant grew poorly after $48 \mathrm{~h}$ on solid minimal medium, however, after longer incubation time it exhibited growth rate comparable to that of the wild type TRAstAWT.

$A$. nidulans strains bearing wild type $s B$ are sensitive to selenate, a toxic analogue of sulfate, under derepressing conditions ( $0.1 \mathrm{mM}$ methionine), opposite to sulfate permease-deficient strains (e.g., sB43 mutants), which are resistant (Piłsyk et al., 2007). In our study, when compared to wild 1 type AstA, the $K_{262} A$ or $K_{264} A$ substitutions hardly affected growth in the presence of selenate, while the resistance to selenate of the $\mathrm{K}_{260} \mathrm{~A}, \mathrm{~K}_{263} \mathrm{~A}, \mathrm{~K}_{263} \mathrm{~L}$ and $\mathrm{K}_{264} \mathrm{~L}$ mutants was increased substantially, so that they could grow on MM-S medium containing $1 \mathrm{mM}$ selenate (Fig. 3) even under derepressing conditions $(0.1 \mathrm{mM}$ methionine).

\section{Central Cytoplasmic Loop mutants can take up sulfate}

Sulfate uptake was measured in transformants of the M111 strain bearing the $s B 43$ mutation and various mutated ast $A$ alleles (Table 1), and compared with the TRAstAWT and TRSBWT strains serving as positive controls. The SB transporter in TRSBWT was more

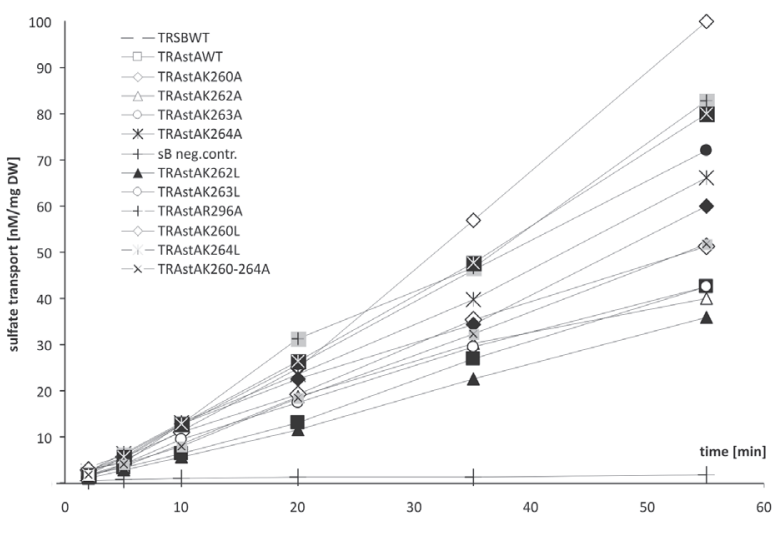

Figure 4. The sulfate uptake by transformants measured as influx of ${ }^{35} \mathrm{SO}_{4}{ }^{2-}$.

The mycelia of the $s B 43$ mutant (negative control) and its transformants: with the $s B$ gene (wild type sulfate permease, positive control), the ast $A$ gene (wild type AstA transporter) or mutated ast $A$ alleles, were grown overnight at $37^{\circ} \mathrm{C}$ in $\mathrm{MM}-\mathrm{S}$ medium containing $0.1 \mathrm{mM}$ methionine as a derepressing source of sulfur. Radioactive $1 \mathrm{mM}$ sulfate was added, and aliquots of the mycelia were collected at the times indicated.

effective in sulfate uptake than the AstA mutants or wild type AstA (Fig. 4, Table 1). The $\mathrm{K}_{262} \mathrm{~A}, \mathrm{~K}_{263} \mathrm{~A}$ and $\mathrm{K}_{260-264} \mathrm{~A}$ mutations did not affect the uptake of sulfate significantly, while the $\mathrm{K}_{260} \mathrm{~A}, \mathrm{~K}_{260} \mathrm{~L}, \mathrm{~K}_{263} \mathrm{~L}, \mathrm{~K}_{264} \mathrm{~A}$ and $\mathrm{K}_{264} \mathrm{~L}$ mutations increased the uptake by $38,51,71.6,64.9$ and $79.7 \%$, respectively, compared to TRAstAW' (Fig. 4, Table 1). $\mathrm{K}_{262} \mathrm{~L}$ decreased sulfate uptake by $16 \%$. Altogether, the mutations affecting individual lysine residues in CCL did not abolish the sulfate uptake, moreover, most of the tested mutations led to even faster sulfate transport.

\section{Mutations in Central Cytoplasmic Loop affect kinetics of sulfate uptake}

Since the mutations affecting CCL did not impair sulfate uptake, it seemed possible that CCL could control its kinetics. Therefore, the effects of these mutations on the kinetic parameters of AstA were next studied. The $K_{\tau}$ values determined for wild type AstA and the main sulfate permease SB were $85 \mu \mathrm{M}$ and $108 \mu \mathrm{M}$, respectively (Fig. 5, Table 1). Each of the four substitutions of a single lysine with alanine or leucine decreased the $K_{\tau}$, with the most pronounced decrease observed in transformants bearing the $\mathrm{K}_{260} \mathrm{~A}, \mathrm{~K}_{260} \mathrm{~L}$ and $\mathrm{K}_{264} \mathrm{~L}$ mutations, by $70.6,57.6$ and $56.4 \%$, respectively (Table 1 ). Conversely, the quadruple substitution of the four lysine residues in CCL with alanine led to an increase of the $K_{\tau}$ by almost $40 \%$.

The $V_{\max }$ for wild type transporters was 0.85 (nmol/ min) for SB, and twice as much (1.53) for AstA, measured per $\mathrm{mg}$ of dry weight (DW) of mycelium (Fig. 5, Table 1). Each substitution of lysine with alanine in AstA led to a lowering of $V_{\max }-$ a high decrease (by 48\%) was observed in the $\mathrm{K}_{263}^{\max } \mathrm{A}$ mutant. Meanwhile, $\mathrm{K}_{262} \mathrm{~L}$ substitution led to the strongest decrease of transport velocity (by $57.5 \%$ ), while two other mutants (TRAstAK ${ }_{263} \mathrm{~L}$ and TRAstAK ${ }_{264} \mathrm{~L}$ ) had significantly increased velocity of transportation (by 82.4 and $142 \%$, respectively). A single $\mathrm{K}_{260} \mathrm{~L}$ mutation, or a quadruple substitution of all four lysine residues in CCL with alanine, did not affect $V_{\max }$ significantly. In summary, the substitutions of the lysine residues located in CCL resulted in various changes of both $V_{\max }$ and $K_{\tau}$, suggesting that these residues are important 

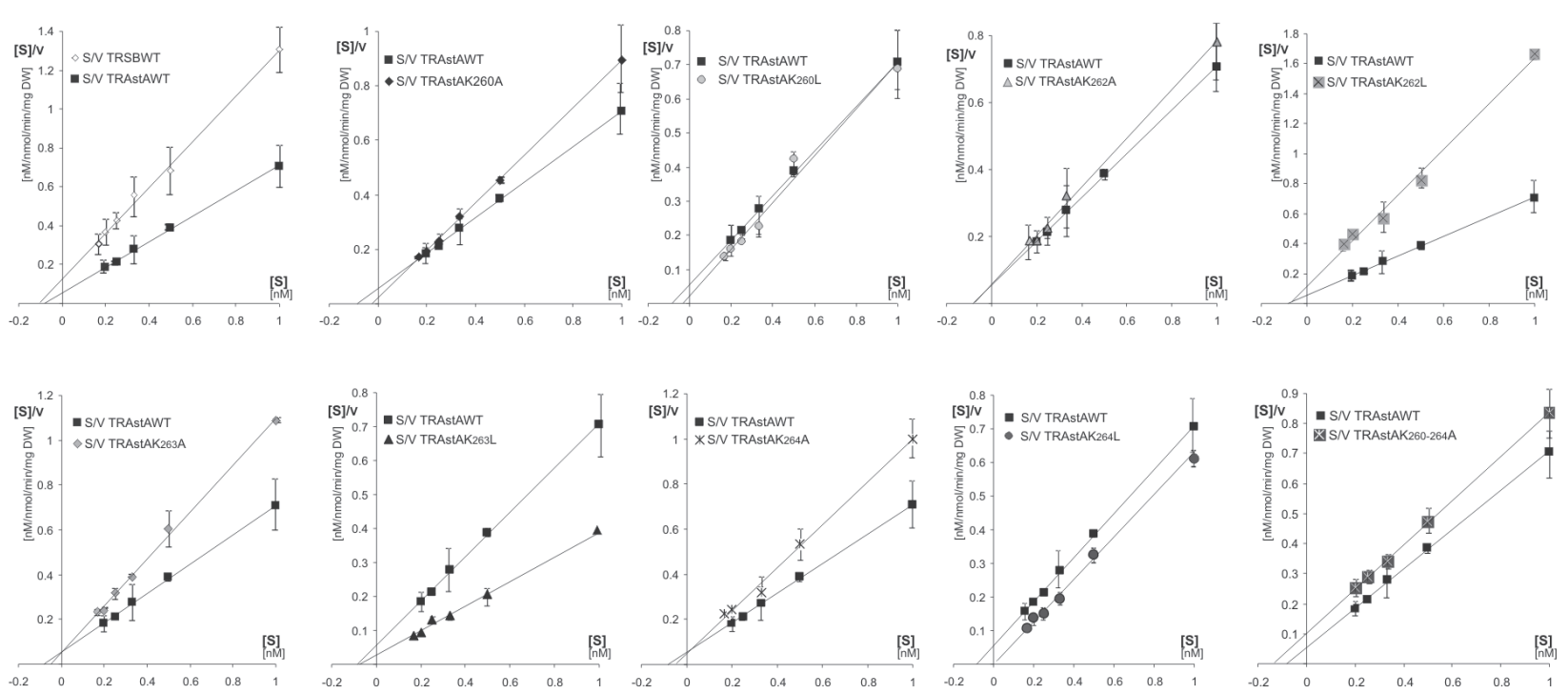

Figure 5. Kinetics of the sulfate uptake by mycelia expressing mutated AstA variants compared to the wild type SB and AstA transporters.

Sulfate was added at concentrations ranging from 0.166 to $1 \mathrm{mM}$ and sulfate uptake was measured as described in Materials and Methods.

for controlling activity of the AstA transporter. The highest increase of $K_{\tau}$ (up to $161 \%$ ) was observed in the quadruple TRAstAK ${ }_{260-264} \mathrm{~A}$ mutant, in which all four lysine residues in CCL were replaced with alanine.

\section{AstA protein localization and stability}

To verify if the mutated AstA proteins were properly located in the cell membrane during the kinetic studies, each mutated AstA variant fused with GFP was expressed in the M111 recipient strain and examined under microscope. In all the transformants, both the GFPtagged wild type AstA protein and its mutated variants were correctly located in the cytoplasmic membrane, both before and after the shift to repressing conditions (Suppl. Fig. S2A at www.actabp.pl). Additionally, the amount of AstA-GFP or its mutated variants was verified by Western dot-blot analysis (Suppl. Fig. S2B at www.actabp.pl), indicating that the AstA protein and its mutant versions were stable in the applied experimental conditions.

\section{Sulfate uptake by AstA is ATP-independent, in contrast to SB (SuIP) permease}

In order to study AstA transport mechanism, we compared the effect of $100 \mu \mathrm{M}$ sodium azide on the radioactive sulfate uptake by the TRSBWT or TRAstAW'T strains (Fig. 6). Sulfate uptake by the SB permease was significantly decreased by azide while Ast A was resistant to the azide treatment. Since azide inhibits ATP-synthase (Bowler et al., 2006), it leads to a decreased intracellular ATP level. Thus, azide-insensitive transport exhibited by the AstA transformant indicates an ATP-independent transport mechanism, contrary to the $\mathrm{SB}$ sulfate permease, which is ATP-dependent (Fig. 6 and earlier published results by Tweedie \& Segel, 1970; Woodin \& Wang, 1989).

\section{DISCUSSION}

Alternative sulfate transporter AstA, a member of the MFS transporters, is found in some fungi, particularly frequently in pathogenic species. Numerous mutations present in the ast $A$ locus (AN10387) in the $A$. nidulans reference strain abolish its functionality, as it was postulated earlier (Piłsyk et al., 2007) and confirmed in this study. Despite of detectable transcription of the $\Psi$ ast $A$ locus (Cerqueira et al., 2014, Sieńko et al., 2014), the protein product is either not produced or nonfunctional. We showed that truncated $\Psi$ ast $A$ was unable to complement the sulfate permease-deficient mutants, even when its ORF was reconstituted with a missing 3 ' sequence encoding the last two TM helices 11 and 12. This result supports our earlier conclusion that the ast $A$ allele derived from the Japanese IAM2006 strain is functional, while $A$. nidulans strains of Glasgow origin contain pseudogene sequences.

Structural studies of various MFS transporters have shown the presence of two transmembrane domains, each one comprising six membrane-spanning helices. The two domains are connected by the central cytoplasmic loop (CCL) (Fig. 1), predictably localized in the way of the transported substrate (Law et al., 2008).

Looking for the role of CCL in AstA, we focused on a highly conserved motif of four lysine residues present in AstA orthologs from various fungi (Fig. 2A). These positively charged residues seemed to interact with a
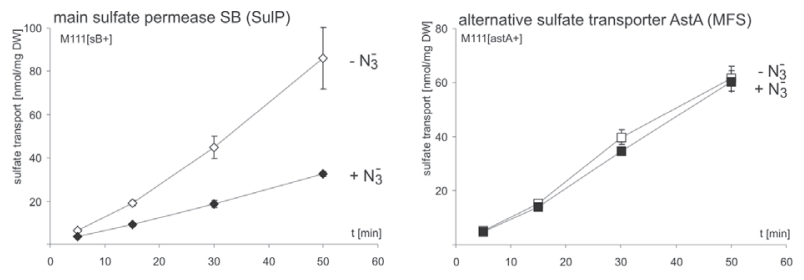

Figure 6. Sulfate uptake by the strains over-expressing SB (A) or AstA (B).

The results are average values from at least four biological replicates. ${ }^{35}$ S-labeled sulfate was added to the mycelia grown in liquid media in the absence or presence of $100 \mu \mathrm{M}$ azide, as indicated in figure legend. The mycelia could take up ${ }^{35} \mathrm{SO}_{4}{ }^{2-}$ as described in Materials and Methods. Samples were collected at four time points and intracellular $\left[{ }^{35} \mathrm{~S}\right]$ sulfate was determined by beta counting. 
negatively charged sulfate ion during translocation, and this assumption was confirmed by the predicted structure of CCL bound with sulfate. Therefore, the role of these four lysine residues $\left(\mathrm{K}_{260}, \mathrm{~K}_{262}, \mathrm{~K}_{263}\right.$ and $\left.\mathrm{K}_{264}\right)$ was subjected to analysis using site-directed mutagenesis.

Surprisingly, neither substitution of each individual lysine with alanine or leucine, nor substitution of all of them with alanine resulted in growth inhibition. Radiolabeling experiments confirmed that the mutated proteins possessed the ability to take up sulfate, albeit with significantly affected kinetics. Except of the quadruple TRAstAK ${ }_{260-264} \mathrm{~A}$ mutant, all variants of AstA with a single lysine in CCL mutated had lower transportation constants $\left(K_{\tau}\right)$ for sulfate, which indicated enhanced affinity for sulfate. However, we did not find any similar potentially beneficial substitution in sequences of AstA orthologues from other fungi. This apparently surprising finding may be explained by AstA's ability to transport sulfite and choline sulfate ester (Holt et al., 2017), which implies that under physiological conditions CCL of AstA should be flexible enough to conform to all these substrates. This versatility of AstA might also prevent substitution of $\mathrm{K}_{263}$ or $\mathrm{K}_{264}$ by a hydrophobic amino acid, which does not occur in nature. While all four single lysine substitutions into alanine resulted in the decreased maximum velocity of sulfate transport, unexpectedly, we found two substitutions among $K$ to
$\mathrm{L}$ mutants $\left(\mathrm{K}_{263} \mathrm{~L}\right.$ and $\left.\mathrm{K}_{264} \mathrm{~L}\right)$ leading to the increased velocity of transportation by 82.4 and $142 \%$, respectively (Table 2). These changes in kinetic properties might result from enhanced CCL flexibility during MFS transporter movements. Regarding that the XylE transporter CCL forms transient latch-like structure (Wisedchaisri et al., 2014), it might be difficult to verify the transient hydrophobic enzyme-substrate interactions relying solely on solid crystal structures.

Among the single amino-acid substitution mutants, TRAst $_{262} \mathrm{~L}$ had the most affected sulfate uptake rate and velocity of transportation $\left(V_{\max }\right)$. Its growth on solid minimal media was also significantly affected after $48 \mathrm{~h}$, however, in a longer time TRAst $\mathrm{A}_{262} \mathrm{~L}$ reached growth rate similar to that of the wild type TRAstAWT strain. None of the $\mathrm{K}_{262}$ substitutions studied here altered $K_{\tau}$, indicating that this lysine 262 is not involved in direct interaction with the sulfate.

The quadruple TRAstAK $\mathrm{T}_{260-264} \mathrm{~A}$ mutant with all four lysine residues substituted, exhibited the most visibly altered substrate transportation, which could also be observed as a decreased selenate resistance on a minimal solid medium. This result suggests that negatively charged lysine residues in wild type CCL of AstA are necessary for the maximum efficiency of the transporter. However, the quadruple $\mathrm{K}_{260-264} \mathrm{~A}$ mutation in CCL did not abolish AstA function completely, as opposed to mutations in

Table 2. List of strains and plasmids

\begin{tabular}{|c|c|c|}
\hline Designation & Genotype or relevant features & Reference or source \\
\hline E. coli strain XL1 Blue & $\begin{array}{l}\text { recA1 endA1 gyrA96 thi-1 hsdR17 supE44 relA1 lac [F' } \\
\text { proAB lacla } Z \Delta M 15 \text { Tn10 (Tetr)]c }\end{array}$ & Stratagene \\
\hline \multicolumn{3}{|l|}{ A. nidulans strains } \\
\hline M111 & sB43 pyrG89 pyroA4 yA2 & laboratory collection \\
\hline M111 $\left[p y r-4^{+}\right]$ & sB43 pyrG89 [ Ncpyr-4+] pyroA4 yA2 & this study \\
\hline TRAstAWT M111 [astA+ ${ }^{+}$, pyr-4+] & sB43 pyrG89 [astA+ Ncpyr-4+] pyroA4 yA2 & this study \\
\hline TRSBWT M111 $\left[s B^{+}, p y r-4^{+}\right]$ & 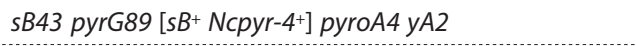 & this study \\
\hline TRAstAK $_{260}$ A M111 $\left[\operatorname{ast}^{\prime} A K_{260} \mathrm{~A}^{+}, p y r-4^{+}\right]$ & sB43 pyrG89 [astAK $\left.260 A^{+} N c p y r-4^{+}\right]$pyroA4 yA2 & this study \\
\hline TRAstAK $_{260} \mathrm{~L} \mathrm{M} 111\left[\right.$ astAK $_{260} \mathrm{~L}^{+}$, pyr-4+] & sB43 pyrG89 [astAK $\left.{ }_{260} L+N c p y r-4+\right]$ pyroA4 yA2 & this study \\
\hline TRAstAK $_{262}$ A M111 [astAK ${ }_{262} \mathrm{~A}^{+}$, pyr- $\left.4^{+}\right]$ & sB43 pyrG89 [astAK $\left.{ }_{262} \mathrm{~A}^{+} \mathrm{Ncpyr}-4^{+}\right]$pyroA4 yA2 & this study \\
\hline TRAstAK $_{262} \mathrm{~L} \mathrm{M} 111\left[\right.$ astAK $_{262} \mathrm{~L}^{+}$, pyr-4+] & sB43 pyrG89 [astAK $\left.{ }_{262} \mathrm{~L}^{+} \mathrm{Ncpyr}-\mathrm{4}^{+}\right]$pyroA4 yA2 & this study \\
\hline TRAstAK $_{263}$ A M111 [astAK ${ }_{263} \mathrm{~A}^{+}$, pyr- $\left.4^{+}\right]$ & sB43 pyrG89 [astAK $\left.{ }_{263} \mathrm{~A}^{+} \mathrm{Ncpyr}-4^{+}\right]$pyroA4 yA2 & this study \\
\hline TRAstAK $_{263} \mathrm{~L}$ M111 [astAK ${ }_{263} \mathrm{~L}^{+}$, pyr-4+] & sB43 pyrG89 [astAK $\left.{ }_{263} \mathrm{~L}+\mathrm{Ncpyr}-4^{+}\right]$pyroA4 yA2 & this study \\
\hline TRAstAK $_{264}$ A M111 [astAK ${ }_{264} \mathrm{~A}^{+}$, pyr-4+] & sB43 pyrG89 [astAK $\left.{ }_{264} \mathrm{~A}+\mathrm{Ncpyr}-4^{+}\right]$pyroA4 yA2 & this study \\
\hline TRAstAK $_{264} \mathrm{~L} \mathrm{M} 111\left[\right.$ astAK $_{264} \mathrm{~L}^{+}$, pyr-4+] & sB43 pyrG89 [astAK $\left.{ }_{264} L^{+} N c p y r-4^{+}\right]$pyroA4 yA2 & this study \\
\hline TRAstAK $_{260-264}$ A M111 [astAK $\mathrm{K}_{260-264} \mathrm{~A}^{+}$, pyr-4+] & sB43 pyrG89 [astAK $\left.260-264 \mathrm{~A}+\mathrm{Ncpyr}-4^{+}\right]$pyroA4 yA2 & this study \\
\hline TRAstAWTGFP M111 [astA-GFP +, pyr-4+] & sB43 pyrG89 [astA-GFP + Ncpyr-4+] pyroA4 yA2 & this study \\
\hline TRAstAK $_{260}$ AGFP M111 [astAK $\left.{ }_{260} \mathrm{~A}^{-G F P}{ }^{+}, p y r-4^{+}\right]$ & $s B 43$ pyrG89 [astAK $\left.{ }_{260} \mathrm{~A}-\mathrm{GFP}+\mathrm{Ncpyr}-4^{+}\right]$pyroA4 yA2 & this study \\
\hline TRAstAK $_{260}$ LGFP M111 [astAK $_{260} \mathrm{~L}^{-G F P+}$, pyr-4+] & sB43 pyrG89 [astAK $\left.260 \mathrm{~L}-\mathrm{GFP}+\mathrm{Ncpyr}-4^{+}\right]$pyroA4 yA2 & this study \\
\hline TRAstAK $_{262}$ AGFP M111 [astAK ${ }_{262}$ A-GFP $^{+}$, pyr-4 $\left.{ }^{+}\right]$ & $s B 43$ pyrG89 [astAK $\left.{ }_{262} \mathrm{~A}-\mathrm{GFP}+\mathrm{Ncpyr}-4^{+}\right]$pyroA4 yA2 & this study \\
\hline 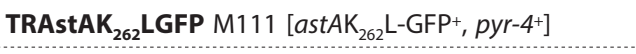 & sB43 pyrG89 [astAK $\left.{ }_{262} \mathrm{~L}-\mathrm{GFP}+\mathrm{Ncpyr}-4^{+}\right]$pyroA4 yA2 & this study \\
\hline TRAstAK $_{263}$ AGFP M111 [astAK ${ }_{263} \mathrm{~A}^{-G F P}+$, pyr-4+] & $s B 43$ pyrG89 [astAK 263 A-GFP + Ncpyr-4+] pyroA4 yA2 & this study \\
\hline TRAstAK $_{263}$ LGFP M111 [astAK ${ }_{263}$ L-GFP+ $^{+}$pyr-4+] & sB43 pyrG89 [astAK $\left.{ }_{263} \mathrm{~L}-\mathrm{GFP}+\mathrm{Ncpyr}-4^{+}\right]$pyroA4 yA2 & this study \\
\hline TRAstAK $_{264}$ AGFP M111 [astAK $\left.{ }_{264} \mathrm{~A}-\mathrm{GFP}^{+}, \mathrm{pyr}^{-4}\right]$ & sB43 pyrG89 [astAK $\left.{ }_{264} \mathrm{~A}-\mathrm{GFP}+\mathrm{Ncpyr}-4^{+}\right]$pyroA4 yA2 & this study \\
\hline TRAstAK $_{264}$ LGFP M111 astAK $_{264}$ L-GFP+ $\left.^{+}, p y r-4^{+}\right]$ & sB43 pyrG89 [astAK $\left.{ }_{264} \mathrm{~L}-\mathrm{GFP}+\mathrm{Ncpyr}-\mathrm{4}^{+}\right]$pyroA4 yA2 & this study \\
\hline TRAstAK $_{260-264}$ AGFP M111 [astAK ${ }_{260-264} \mathrm{~A}^{-G F P+}$, pyr- $\left.4^{+}\right]$ & sB43 pyrG89 [astAK $\left.{ }_{260-264} \mathrm{~A}-\mathrm{GFP}+\mathrm{Ncpyr}-4^{+}\right]$pyroA4 yA2 & this study \\
\hline Plasmids & description & \\
\hline pBluescript KS(-) & cloning vector, Ampr & Stratagene \\
\hline
\end{tabular}




\begin{tabular}{|c|c|c|}
\hline HELp1 & $\begin{array}{l}\text { increases } A \text {. nidulans transformation efficiency about } \\
200 \text { fold }\end{array}$ & $\begin{array}{l}\text { Gems \& Clutterbuck } \\
1993\end{array}$ \\
\hline kPG23B & bearing entire $N$. crassa pyr-4 in pBluescript II KS(-) & laboratory collection \\
\hline 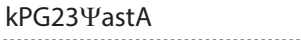 & bearing $\Psi$ ast $A$ pseudogene in $\mathrm{kPG} 23 \mathrm{~B}$ & this study \\
\hline kPB611-12 & $\begin{array}{l}\text { bearing } \Psi \text { ast } A \text { pseudogene with reconstituted } \\
11-12 \text { TM-encoding sequence and } N \text {. crassa pyr- } 4 \text { cas- } \\
\text { sette }\end{array}$ & this study \\
\hline kPSB1 & bearing entire $A$. nidulans $s B$ gene in pBluescript II KS(-) & Piłsyk et al. 2007 \\
\hline kPMS11-52 & $\begin{array}{l}\text { BamHI-Sall insert bearing astA gene in pBluescript } \\
\text { KS(-) vector }\end{array}$ & Piłsyk et al. 2007 \\
\hline kPMS11-524 & $\begin{array}{l}\text { kPMS11-52 with N. crassa pyr-4 cassette ligated into } \\
\text { Pvull site }\end{array}$ & this study \\
\hline kPMS11-524K260A & kPMS11-524-derived mutated $\mathrm{K}_{260} \mathrm{~A}$ ast $\mathrm{A}$ allele & this study \\
\hline kPMS11-524K260L & KPMS11-524-derived mutated $\mathrm{K}_{260} \mathrm{~L}$ ast $A$ allele & this study \\
\hline kPMS11-524K262A & kPMS11-524-derived mutated $\mathrm{K}_{262} \mathrm{~A}$ ast $\mathrm{A}$ allele & this study \\
\hline kPMS11-524K262L & kPMS11-524-derived mutated $\mathrm{K}_{262} \mathrm{~L}$ ast $A$ allele & this study \\
\hline kPMS11-524K263A & kPMS11-524-derived mutated $\mathrm{K}_{263} \mathrm{~A}$ ast $\mathrm{A}$ allele & this study \\
\hline kPMS11-524K263L & kPMS11-524-derived mutated $\mathrm{K}_{263} \mathrm{~L}$ ast $A$ allele & this study \\
\hline kPMS11-524K264A & kPMS11-524-derived mutated $\mathrm{K}_{264} \mathrm{~A}$ ast $\mathrm{A}$ allele & this study \\
\hline kPMS11-524K264L & kPMS11-524-derived mutated $\mathrm{K}_{264} \mathrm{~L}$ ast $A$ allele & this study \\
\hline kPMS11-524K260-264A & kPMS11-524-derived mutated $\mathrm{K}_{260-264} \mathrm{~A}$ ast $\mathrm{A}$ allele & this study \\
\hline kPMS11-5243 & $\begin{array}{l}\text { kPMS11-524-derived astA gene fused with GFP-enco- } \\
\text { ding gene }\end{array}$ & this study \\
\hline kPMS11-5243K260A & kPMS11-5243-derived mutated $\mathrm{K}_{260} \mathrm{~A}$ ast $\mathrm{A}$ allele & this study \\
\hline kPMS11-5243K260L & kPMS11-5243-derived mutated $K_{260} L$ ast $A$ allele & this study \\
\hline kPMS11-5243K262A & kPMS11-5243-derived mutated $\mathrm{K}_{262} \mathrm{~A}$ ast $\mathrm{A}$ allele & this study \\
\hline kPMS11-5243K262L & kPMS11-5243-derived mutated $K_{262} \mathrm{~L}$ ast $A$ allele & this study \\
\hline kPMS11-5243K263A & kPMS11-5243-derived mutated $\mathrm{K}_{263} \mathrm{~A}$ ast $\mathrm{A}$ allele & this study \\
\hline kPMS11-5243K263L & kPMS11-5243-derived mutated $K_{263} L$ ast $A$ allele & this study \\
\hline kPMS11-5243K264A & kPMS11-5243-derived mutated $\mathrm{K}_{264} \mathrm{~A}$ ast $\mathrm{A}$ allele & this study \\
\hline kPMS11-5243K264L & kPMS11-5243-derived mutated $K_{264} \mathrm{~L}$ ast $A$ allele & this study \\
\hline kPMS11-5243K260-264A & kPMS11-5243-derived mutated $\mathrm{K}_{260-264} \mathrm{~A}$ ast $A$ allele & this study \\
\hline
\end{tabular}

CCL of C. albicans Mdr1 multidrug transporter (Mandal et al., 2012). Shortening of CCL in Mdr1 eliminated the drug resistance, suggesting an important role of the loop for the functioning of this transporter. Since insertional mutagenesis restoring the loop length did not result in a functional transporter, one can infer that the amino acid composition of CCL is more relevant to substrate transport than its mere length.

Altogether, our results indicate that CCL is not essential for the function of the entire transporter, but seems to be engaged in controlling of AstA activity. Interestingly, it has been found earlier that CCL of the E. coli lactose permease is involved in allosteric regulation by the glucose-specific enzyme IIA of the phosphoenolpyruvate: sugar phosphotransferase system (Hoischen et al., 1996, Seok et al., 1997). Similarly, CCL in the human GLUT1 transporter mediates ATPdependent inhibition of glucose transport (Blodgett et al., 2007). In similar way, the AstA CCL could interact with the sulfate and form an allosteric site controlling the transporter's activity. Since AstA is ATP-independent, as we have shown (Fig. 6), fungi bearing this gene may have a higher evolutionary fitness under the low oxygen conditions, when ATP synthesis is limited, for instance in a situation of the pathogens infecting host tissue.
The findings presented by Weinglass and Kaback (Weinglass \& Kaback, 2000) show that the cytoplasmic loop between helices VI and VII functions as a temporal delay spacer upon insertion of the first six helices into the translocon, and their subsequent movement into the bilayer before insertion of the last six helices. Additionally, sequence alignments of LacY CCL indicate that this region is very poorly conserved (Weinglass \& Kaback, 2000). Detailed studies of E. coli LacY by Frillingos and coworkers (Frillingos et al., 1998) and Weinglass and Kaback (Weinglass \& Kaback, 2000) show that the bacterial LacY CCL plays no direct role in the substrate transportation. Bacterial MFS may be easily split into two halves discarding CCL, and the generated mutant exhibits expression and activity comparable to the wild type (Weinglass \& Kaback, 2000). Even an introduction of the stretches of random hydrophilic amino acid into the poorly active $\Delta 20$ aa CCL mutant, partially restores its activity, up to the $30-50 \%$ of the wild-type level. Thus, in a case of bacterial MFS transporters, CCL seems not to be particularly important for the protein function. In contrast to what was observed for the bacterial LacY transporter and its CCL, our studies indicate that AstA CCL sequence has tightly conserved length and high 
amino acid homology (over 70\%) among numerous fungal species (Fig. 2A).

In this paper, we demonstrated that eukaryotic MFS may have different kinetics than bacterial transporters. In contrast to E. coli $\mathrm{LacY}$, the fungal AstA mutants: single substituted $\mathrm{K}_{260}, \mathrm{~K}_{264}$ or quadruple $\mathrm{K}_{260-264} \mathrm{~A}$ led to a competitive inhibition of sulfate transportation by altering $K_{\tau}$.

Since the lysine substitutions in CCL resulted in the altered sulfate transportation constants $(K)$ in the AstA transporters, it seems likely that CCL limits the AstA affinity for substrate under the conditions of high intracellular sulfate concentration. Consequently, the substitutions of the lysine residues in CCL could abolish that allosteric regulation, resulting in an altered sulfate affinity of the mutated AstA variants. The most pronounced shift in $K_{\tau}$ was observed for quadruple TRAstAK ${ }_{260-264} \mathrm{~A}$ mutant, which was also susceptible to selenate, a toxic analog of sulfate. Since an alteration of a substrate binding constant usually refers to a competitive inhibition of the enzyme binding site (Strelow et al., 2012), our results indicate that CCL indeed interacts with the sulfate. Whether the proposed binding of sulfate by CCL would be assisted by interaction with other proteins, as it is in the case of the E. coli lactose permease, remains an open question.

The observed physiological effects of the mutations affecting CCL could be alternatively explained, if one assumed that CCL formed a proofreading centre (or a checkpoint), controlling the parameters of the incoming substrate. Such possibility is supported by our observation that the $\mathrm{K}_{260} \mathrm{~A}, \mathrm{~K}_{260} \mathrm{~L}, \mathrm{~K}_{263} \mathrm{~A}$ and $\mathrm{K}_{264} \mathrm{~L}$ mutants of Ast A with decreased $K_{\tau}$ (Table 2 ) were more resistant to selenate (Fig. 3), suggesting that these mutations could affect interaction with selenate rather than with the sulfate. Hence, CCL could be a flexible goalkeeper of the AstA transporter, forming a transient substrate-interacting pocket, acting as a checkpoint for the molecules entering the cell.

Numerous biochemical studies characterizing the MFS transporters were focused on substrate translocation pore, located within TM helices. However, $K_{\tau}$ or $K_{\mathrm{m}}$ values are still poorly studied, and CCL has not been well investigated. The mutations introduced in substrate binding site of MFS transporters usually lead to a pronounced 10-fold $K_{\mathrm{m}}$ alteration (Will et al., 1998; SahinTóth et al., 1999). Among some previously described enzymes, S-1,2-propanediol oxidoreductase (FucO) alters its substrate specificity substantially upon just a single point mutation $\mathrm{L}_{259} \mathrm{~V}$ in the substrate-binding site, while its $K_{\mathrm{m}}$ increases just two-fold (Blikstad et al., 2014). In case of the higher eukaryotes, some mutated enzymes, it was shown that human galactokinase, point-mutated in its substrate-binding site $\left(\mathrm{A}_{108} \mathrm{~V}\right)$, has $K_{\mathrm{m}}$ only weakly altered (30\% decrease) and its kinetic parameters are almost comparable to the wild type (Timson \& Reece, 2003). However, the $A_{198} V$ mutation in galactokinase is severely manifested on the cellular and organism level, with a clinical phenotype of a tendency to develop cataracts (Okano et al., 2001). Since there is no data referring to kinetic parameters of eukaryotic CCL, it was not possible to compare our results to published values.

Crystal studies of the bacterial XylE transporter revealed that CCL can act as a structural linker between the N- and C-terminal domains of MFS proteins, transiently forming a latch-like structure (Wisedchaisri et al., 2014). Till now, CCL was regarded as a structural linker only, but we have shown that this loop can affect the substrate uptake. Considering that some mutations locat- ed within the linker resulted in the significant $K_{\tau}$ shifts, CCL may also participate in substrate recognition. Summarizing, the presented results suggest that the four lysine residues located within the CCL linker region are not necessary for the sulfate transport, but they select for the incoming substrate and facilitate its uptake.

\section{Acknowledgements}

We are indebted to Dr. Małgorzata Lichocka for her help in confocal microscopy and to Prof. Andrzej Paszewski for his careful reading of the manuscript. We are also indebted to Dr. Joanna Kamińska for a gift of the anti- $\alpha$ Pma1p antibodies.

\section{Acknowledgements of Financial Support}

This work was supported by the State Committee for Scientific Research/National Center of Science (NCN), grant number N N303 814040 to S.P. and by The European Regional Development Fund and Innovative Economy, Poland, grant number UDAPOIG.01.03.01-14-038/09 to J.S.K. The equipment used was sponsored in part by the Centre for Preclinical Research and Technology (CeP'T), a project co-sponsored by The Innovative Economy, The National Cohesion Strategy of Poland.

\section{REFERENCES}

Abramson J, Smirnova I, Kasho V, Verner G, Kaback HR, Iwata S (2003) Structure and mechanism of the lactose permease of Escherichia coli. Science 301: 610-615. https://doi.org/10.1126/science. 1088196

Alper SL, Sharma AK (2013) The SLC26 gene family of anion transporters and channels. Mol Aspects Med 34: 494-515. https://doi. org/10.1016/j.mam.2012.07.009

Altschul SF, Lipman DJ (1990) Protein database searches for multiple alignments. Proc Natl Acad Sci USA 87: 5509-5513

Arst HN Jr (1968) Genetic analysis of the first steps of sulphate metabolism in Aspergillus nidulans. Nature 219: 268-270. https:// doi:10.1038/219268a0

Biswas C, Djordjevic JT, Zuo X, Boles E, Jolliffe KA, Sorrell TC, Chen SC (2013) Functional characterization of the hexose transporter Hxt13p: an efflux pump that mediates resistance to miltefosine in yeast. Fungal Genet Biol 61: 23-32. https://doi.org/10.1016/j. fgb.2013.09.005

Blikstad C, Dahlström KM, Salminen TA, Widersten M (2014) Substrate scope and selectivity in offspring to an enzyme subjected to directed evolution. FEBS J 281: 2387-2398. https://doi.org/10.1111/ febs. 12791

Blodgett DM, De Zutter JK, Levine KB, Karim P, Carruthers A (2007) Structural basis of GLUT1 inhibition by cytoplasmic ATP. J Gen Physiol 130: 157-168. https://doi.org/10.1085/jgp.200709818

Bourne Y, Dannenberg J, Pollmann V, Marchot P, Pongs O (2001) Immunocytochemical localization and crystal structure of human frequenin (neuronal calcium sensor 1). I Biol Chem 276: 11949_ 11955. https://doi.org/10.1074/jbc.M009373200

Bowler MW, Montgomery MG, Leslie AG, Walker JE (2006) How azide inhibits ATP hydrolysis by the F-ATPases. Proc Natl Acad Sci U S A 103: 8646-8649. https://doi.org/10.1073/pnas.0602915103

Buchan DW, Minneci F, Nugent TC, Bryson K, Jones DT (2013). Scalable web services for the PSIPRED Protein Analysis Workbench. Nucleic Acids Res 41 (Web Server issue): W340-W348. https://doi. org/10.1093/nar/gkt381

Cerqueira GC, Arnaud MB, Inglis DO, Skrzypek MS, Binkley G, Simison M, Miyasato, SR, Binkley J, Orvis J, Shah P, Wymore F, Sherlock G, Wortman JR (2014). The Aspergillus Genome Database: multispecies curation and incorporation of RNA-Seq data to improve structural gene annotations. Nucleic Acids Res 42: D705-D710. https://doi.org/10.1093/nar/gkt1029

Clutterbuck AJ (1994) Linkage map and locus list. Prog Ind Microbiol 29: $791-824$

Dang S, Sun L, Huang Y, Lu F, Liu Y, Gong H, Wang J, Yan N (2010) Structure of a fucose transporter in an outward-open conformation. Nature 467: 734-738. https://doi.org/10.1038/nature09406

Edgar RC (2004) MUSCLE: multiple sequence alignment with high accuracy and high throughput. Nucleic Acids Res 32: 1792-1797. https://doi.org/10.1093/nar/gkh340 
Ethayathulla AS, Yousef MS, Amin A, Leblanc G, Kaback HR (2014) Structure-based mechanism for $\mathrm{Na}+/$ melibiose symport by MelB. Nature Commun 5: 3009. https://doi.org/10.1038/ncomms4009

Frillingos S, Sahin-Tóth M, Wu J, Kaback HR (1998) Cys-scanning mutagenesis: a novel approach to structure function relationships in polytopic membrane proteins. FASEB J 12: 1281-1299. https://doi. org/10.1096/fasebj.12.13.1281

Gems DH, Clutterbuck AJ (1993) Co-transformation with autonomously-replicating helper plasmids facilitates gene cloning from an Aspergillus nidulans gene library. Curr Genet 24: 520-524

Hirai T, Heymann JA, Shi D, Sarker R, Maloney PC, Subramaniam S (2002) Three-dimensional structure of a bacterial oxalate transporter. Nat Struct Biol 9: 597-600. https://doi.org/10.1038/nsb821

Hofmann K, Stoffel W (1993) TMbase - A database of membrane spanning proteins segments. Biol Chem Hoppe-Seyler 374: 166

Hoischen C, Levin J, Pitaknarongphorn S, Reizer J, Saier MH Jr (1996) Involvement of the central loop of the lactose permease of Escherichia coli in its allosteric regulation by the glucose-specific enzyme IIA of the phosphoenolpyruvate-dependent phosphotransferase system. J Bacteriol 178: 6082-6086

Holt S, Kankipati H, De Graeve S, Van Zeebroeck G, FoulquiéMoreno MR, Lindgreen S, Thevelein JM (2017) Major sulfonate transporter Soa1 in Saccharomyces cerevisiae and considerable substrate diversity in its fungal family. Nat Commun 8: 14247. https://doi. org/10.1038/ncomms14247

Iancu CV, Zamoon J, Woo SB, Aleshi, A, Choe JY (2013) Crystal structure of a glucose $/ \mathrm{H}^{+}$symporter and its mechanism of action. Proc Natl Acad Sci U S A 110: 17862-17867. https://doi. org/10.1073/pnas.1311485110

Kasahara T, Ishiguro M, Kasahara M (2006) Eight amino acid residues in transmembrane segments of yeast glucose transporter Hxt2 are required for high affinity transport. I Biol Chem 281: 18532-18538. https://doi.org/10.1074/jbc.M602123200

Kasahara T, Maeda M, Bole,s E, Kasahara M (2009) Identification of a key residue determining substrate affinity in the human glucose transporter GLUT1. Biochim Biophys Acta 1788: 1051-1055. https:// doi.org/10.1016/j.bbamem.2009.01.014

Kertesz MA (2001) Bacterial transporters for sulfate and organosulfur compounds. Res Microbiol 152: 279-290

Kuwano T, Shirataki C, Itoh Y (2008) Comparison between polyethylene glycol- and polyethylenimine-mediated transformation of $A$ spergillus nidulans. Curr Genet 54: 95-103. https://doi.org/10.1007/ s00294-008-0204-Z

Law CJ, Maloney PC, Wang DN (2008) Ins and outs of major facilitator superfamily antiporters. Annu Rev Microbiol 62: 289-305. https:// doi.org/10.1146/annurev.micro.61.080706.093329

Lemieux MJ, Huan, Y, Wang DN (2004) The structural basis of substrate translocation by the Escherichia coli glycerol-3-phosphate transporter: a member of the major facilitator superfamily. Curr Opin Struct Biol 14: 405-412. https://doi.org/10.1016/j.sbi.2004.06.003

Letunic I, Bork P (2017) 20 years of the SMART protein domain annotation resource. Nucleic Acids Res 46(D1): D493-D496. https:// doi:10.1093/nar/gkx922

Lowry OH, Rosebrough NJ, Farr AL, Randall RJ (1951) Protein measurement with the Folin phenol reagent. J Biol Chem 193: 265-275

Łukaszkiewicz Z, Paszewski A (1976) Hyper-repressible operator-type mutant in sulphate permease gene of Aspergillus nidulans. Nature 259: 337-338. https://doi.org/10.1038/259337a0

Mandal A, Kumar A, Singh A, Lynn AM, Kapoor K, Prasad R (2012) A key structural domain of the Candida albicans Mdr1 protein. Biochem J 445: 313-322. https://doi.org/10.1042/BJ20120190

Martinelli SD (1994) Gene symbols. Prog Ind Microbiol 29: 825-827

Okano Y, Asada M, Fujimoto A, Ohtake A, Murayama K, Hsiao KJ, Choeh K, Yang Y, Cao Q, Reichardt JK, Niihira S, Imamura $\mathrm{T}$, Yamano $\mathrm{T}$ (2001) A genetic factorfor age-related cataract: identification and characterization of a novel galactokinase variant, 'Osaka', in Asians. Am J Hum Genet 68: 1036-1042. https://doi. org/10.1086/319512

Pasrija R, Banerjee D, Prasad R (2007) Structure and function analysis of CaMdr1p, a major facilitator superfamily antifungal efflux transporter protein of Candida albicans: identification of amino acid residues critical for drug/ $\mathrm{H}+$ transport. Eukaryot Cell 6: 443-453. https://doi.org/10.1128/EC.00315-06

Patron M, Checchetto V, Raffaello A, Teardo E, Reane DV, Mantoan M, Granatiero V, Szabo I, De Stefani D, Rizzuto R (2014) MICU1 and MICU2 finely tune the mitochondrial $\mathrm{Ca}^{2+}$ uniporter by exerting opposite effects on MCU activity. Mol Cell 53: 726-737. https://doi.org/10.1016/j.molcel.2014.01.013

Paulsen IT, Brown MH, Skurray RA (1996) Proton-dependent multidrug efflux systems. Microbiol Rev 60: 575-608
Pedersen BP, Kumar H, Waight AB, Risenmay AJ, Roe-Zurz, Z., Chau BH, Schlessinger A, Bonomi M, Harries W, Sali A, Johri AK, Stroud RM (2013) Crystal structure of a eukaryotic phosphate transporter. Nature 496: 533-536. https://doi.org/10.1038/nature12042

Piłsyk S, Natorff R, Sieńko M, Paszewski A (2007) Sulfate transport in Aspergillus nidulans: a novel gene encoding alternative sulfate transporter. Fungal Genet Biol 44: 715-725. bttps://doi.org/10.1016/j. fgb.2006.11.007

Piłsyk S, Paszewski A (2009) Sulfate permeases - phylogenetic diversity of sulfate transport. Acta Biochim Pol 56: 375-384

Piłsyk S, Natorff R, Gawińska-Urbanowicz H, Kruszewska JS (2015) Fusarium sambucinum ast $A$ gene expressed during potato infection is a functional orthologue of Aspergillus nidulans ast A. Fungal Biol 119: 509-517. https://doi.org/10.1016/j.funbio.2015.02.002

Rost B, Yachdav G, Liu J (2004) The PredictProtein Server. Nucleic Acids Res 32 (Web Server issue): W321-W326. https://doi. org/10.1093/nar/gkh377

Roth V (2006) Doubling Time Computing, Available from: http:// www.doubling-time.com/compute.php

Roy A, Kucukural A, Zhang Y (2010) I-TASSER: a unified platform for automated protein structure and function prediction. Nature Protocols 5: 725-738. https://doi.org/10.1038/nprot.2010.5

Roy A, Yang J, Zhang, Y (2012) COFACTOR: an accurate comparative algorithm for structure-based protein function annotation. Nucleic Acids Res 40 (Web Server issue): W471-7. https://doi. org/10.1093/nar/gks372

Sahin-Tóth M, le Coutre J, Kharabi D, le Maire G, Lee JC, Kaback HR (1999) Characterization of Glu126 and Arg144, two residues that are indispensable for substrate binding in the lactose permease of Escherichia coli. Biochemistry 38: 813-819. https://doi.org/10.1021/ bi982200h

Sambrook J, Fritsch EF, Maniatis T (1989) Molecular cloning: a laboratory manual. Cold Spring Harbor Laboratory Press. https://doi. org/10.1016/0092-8674(90)90210-6

Sayle RA, Milner-White EJ (1995) RASMOL: biomolecular graphics for all. Trends Biochem Sci 20: 374. https://doi.org/10.1016/S09680004(00)89080-5

Seok YJ, Sun J, Kaback HR, Peterkofsky A (1997) Topology of allosteric regulation of lactose permease. Proc Natl Acad Sci U S A 94: 13515-13519. https://doi.org/10.1073/pnas.94.25.13515

Sieńko M, Natorff R, Skoneczny M, Kruszewska J, Paszewski A, Brzywczy J (2014) Regulatory mutations affecting sulfur metabolism induce environmental stress response in Aspergillus nidulans. Fungal Genet Biol 65: 37-47. https://doi.org/10.1016/j.fgb.2014.02.001

Strelow J, Dewe W, Iversen PW, Brooks HB, Radding JA, McGee J, Weidner J (2012) Mechanism of Action Assays for Enzymes, In Assay Guidance Manual, Sittampalam GS, Coussens NP, Nelson H et al, eds, Eli Lilly \& Company and the National Center for Advancing Translational Sciences, 2004

Sun L, Zeng X, Yan C, Sun X, Gong X, Rao Y, Yan N (2012) Crystal structure of a bacterial homologue of glucose transporters GLUT14. Nature 490: 361-366. https://doi.org/10.1038/nature11524

Timson DJ, Reece RJ (2003) Functional analysis of disease-causing mutations in human galactokinase. Eur J Biochem 270: 1767-1774. https://doi.org/10.1046/j.1432-1033.2003.03538.x

Tweedie JW Segel IH (1970) Specificity of transport processes for sulfur, selenium, and molybdenum anions by filamentous fungi. Biochim Biophys Acta 196: 95-106. https://doi.org/10.1016/00052736(70)90170-7

Weinglass AB, Kaback HR (2000) The central cytoplasmic loop of the major facilitator superfamily of transport proteins governs efficient membrane insertion. Proc Natl Acad Sci U S A 97: 8938-8943. https://doi.org/10.1073/pnas.140224497

Will A, Grassl R, Erdmenger J, Caspari T, Tanner W (1998) Alteration of substrate affinities and specificities of the Chlorella Hexose/H+ symporters by mutations and construction of chimeras. J Biol Chem 273: 11456-11462. https://doi.org/10.1074/jbc.273.19.11456

Wisedchaisri G, Park MS, Iadanza MG, Zhen H, Gonen T (2014) Proton-coupled sugar transport in the prototypical major facilitator superfamily protein XylE. Nat Commun 5: 4521. https://doi. org/10.1038/ncomms5521

Woodin TS Wang JL (1989) Sulfate permease of Penicillium duponti. Exp Mycol 13:380-391. https://doi.org/10.1016/0147-5975(89)90034-0

Yin Y, He X, Szewczyk P, Nguyen T, Chang G (2006) Structure of the multidrug transporter EmrD from Escherichia coli. Science 312: 741-744. https://doi.org/10.1126/science.1125629

Zhang Y (2008) I-TASSER server for protein 3D structure prediction. BMC Bioinformatics 9: 40. https://doi.org/10.1186/1471-2105-9-40 